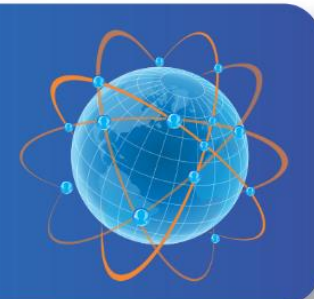

\title{
Empowering Farmer Through the New Paddy Printing Program in Way Kanan District
}

Authors : Desi Yunita, Ahmad Thoriq

Published by : Departemen of Sociology, Faculty of Social and Political Science, Universitas Padjadjaran

Accepted : November 2017; Approved : December 2017

Sosiogobal: Jumal Pemikiran dan Penelitian Sosiologi is the Department of Sociology, Faculty of Social and Political Science, Universitas Padjadjaran flagship journal. The Sosioglobal journal founded in 2016 with the mission to publish original works of interest to the discipline of sociology in general, sociological thinking, new theoretical developments, results of research that enhance understanding of fundamental social processes, and methodological innovations. We are welcome a research article, working paper, theoretical/conceptual and methodological review to submit to our journal. In addition, we are accept relevant book review that currently publish and enrich sociological perspectives. Please submit article to http://jurnal.unpad.ac.id/sosioglobal

To cite this article :

Yunita, Desi, Ahmad Thoriq.2017. Empowering Farmer Through the New Paddy Printing Program in Way Kanan District. Sosioglobal : Jurnal Pemikiran dan Penelitian Sosiologi 2(1):73-83. 


\title{
EMPOWERING FARMER THROUGH THE NEW PADDY PRINTING PROGRAM IN WAY KANAN DISTRICT
}

\author{
Desi Yunita ${ }^{1}$, Ahmad Thoriq ${ }^{2}$ \\ Prodi Sosiologi, Fakultas Ilmu Sosial dan Ilmu Politik, Universitas Padjadjaran \\ desi.yunita@unpad.ac.id
}

\begin{abstract}
ABSTRAK
Tulisan ini menjelaskan kelayakan program pencetakan sawah baru secara sosial di kabupaten Way Kanan serta bagaimana program pencetakan sawah baru ini dapat mendorong perubahan pada masyarakat di Kabupaten Way Kanan. Beberapa aspek yang menjadi perhatian dalam penelitian ini diantaranya adalah usia, pendidikan, jumlah anggota keluarga, luas lahan yang diikutkan dalam program, serta kondisi sosial masyarakat. Metode yang digunakan dalam penelitian ini adalah kualitatif, agar data yang diperoleh semakin lengkap penelitian ini juga menggunakan kuesioner. Hasil penelitian memperlihatkan bahwa terjadinya perubahan skema program telah menyebabkan beberapa kelompok masyarakat menarik diri dari program. Hal itu disebabkan oleh adanya upaya manipulasi yang dilakukan oleh masyarakat terkait program ini. Bagi masyarakat yang mengikuti program, skema pembentukan kelompok dalam program telah mendorong menguatnya modal sosial masyarakat yang ditunjukkan dengan menguatnya kepercayaan, keterhubungan, dan jaringan sosial. Selain itu, program ini juga meningkatkan solidaritas dan kerjasama serta keterhubungan antar kelompok petani.
\end{abstract}

Kata kunci: masyarakat petani, cetak sawah, solidaritas, kerjasama, keterhubungan

\begin{abstract}
This paper describes the social feasibility of a new paddy printing program in Way Kanan district. As well as how this program can drive change in communities in Way Kanan District. Some aspects of concern in this study are age, education, number of family members, land area included in the program, and social condition of the community. The method used in this study is qualitative, to complement the data also used questionnaire. The analysis of this research uses social capital theory. The results of the study show that the change of program scheme has caused some community groups to withdraw from the program. This is caused by any manipulation efforts undertaken by the community related to this program. For the community who participated in the program, the scheme of group formation in the program has encouraged the strengthening of community social capital as demonstrated by the strengthening of trust, connectedness, and social network. In addition, the program also promotes solidarity and cooperation, and connectivity among farmer groups.
\end{abstract}

Keywords: farming communities, paddy fields, solidarity, cooperation, connectedness

\footnotetext{
2. Fakultas Teknologi Industri Pertanian, Universitas Padjadajaran thoriq.unpad@gmail.com
} 


\section{PENDAHULUAN}

Prioritas pemerintahan pada bidang pangan diantaranya adalah mencukupi kebutuhan pangan dan produksi dalam negeri; mengatur kebijakan pangan secara mandiri; serta melindungi dan mensejahterakan petani sebagai pelaku utama usaha pertanian. Tiga hal inilah yang ingin dicapai pemerintah dalam rangka mewujudkan kedaulatan pangan dalam negeri. Dari tiga hal tersebut tersirat bahwa mencapai kedaulatan pangan harus diawali dengan meningkatnya kemampuan untuk swasembada pangan dan selanjutnya secara bertahap diiringi dengan meningkatnya nilai tambah usaha pertanian dalam rangka meningkatkan kesejahteraan petani. Ketahanan pangan menjadi sangat penting artinya karena kondisi pangan yang stabil dapat menjadi jaminan stabilitas nasional suatu negara secara politik, sosial, ekonomi, dan keamanan. Lebih jauh lagi, keberhasilan dalam mencapai tiga tujuan tersebut juga akan memberikan arah pembangunan pertanian yang tepat sehingga tingkat kesejahteraan petani juga akan terus mengalami peningkatan. Salah satu upaya yang dilakukan oleh pemerintah dalam rangka mencapai target tersebut adalah dengan mendorong pencetakan sawah baru di daerah-daerah yang masih memiliki potensi lahan untuk dikembangkan sawah baru tersebut. selain itu, program pencetakan sawah baru ini juga dilakukan dalam rangka memenuhi kuota lahan pertanian padi yang selama kurun satu dekade belakangan terus mengalami pengurangan akibat adanya konversi lahan pertanian menjadi lahan peruntukkan lain.

Jika dilihat jangka waktunya program pencetakan sawah baru ini telah dimulai sejak tahun 2006, dan pada tahun 2015 dari 23 ribu hektar yang ditargetkan tercapai 20 ribu hektar. Dalam laman detik.com diketahui bahwa pada tahun 2016 dari target cetak sawah baru sebesar 132.167 hektar terealisasi sebesar 129.096 hektar. Hal tersebut memperlihatkan telah terjadi percepatan dalam realisasi program pencetakan sawah baru. Salah satu faktor yang mempengaruhi besarnya lonjakan tersebut adalah karena digandengnya TNI untuk terlibat aktif dalam menyukseskan program pencetakan sawah baru tersebut. Senada dengan hal itu, katadata.co.id berdasarkan data dari pusat data dan informasi Kementerian Pertanian mencatat bahwa realisasi cetak sawah dari 2014-2016 adalah sebanyak 26.607 hektar, 20.070 hektar, dan 129.096 hektar.

Terus meningkatnya luasan lahan yang dicetak setiap tahun selain menunjukkan bahwa kebutuhan pangan dalam negeri terus meningkat, disisi lain juga mengindikasikan masifnya perubahan peruntukkan lahan pertanian menjadi areal peruntukkan lain yang mana hal tersebut dipengaruhi oleh tingkat pertumbuhan penduduk di Indonesia. Kementerian pertanian menyebutkan bahwa konversi lahan dari sawah menjadi lahan peruntukkan lain 
diperkirakan mencapai 100.000 hektar per tahunnya. Adanya alih fungsi lahan tersebutlah yang melandasi pemerintah mengembangkan program pencetakan sawah baru.

Salah satu daerah yang direncanakan untuk dilakukan upaya pencetakan sawah baru pada tahun 2016 adalah kabupaten Way Kanan di Provinsi Lampung. Usulan yang diterima menyebutkan bahwa terdapat dua kecamatan yang mengusulkan program pencetakan sawah baru, yaitu Kecamatan Baradatu dan Kecamatan Banjit.

Untuk menentukan kelayakan suatu lokasi, beberapa kriteria yang ditetapkan oleh kementerian pertanian diantaranya; status kepemilikan tanah jelas apakah tanah merupakan milik pribadi, tanah rakyat (marga) atau tanah negara yang diizinkan untuk digarap oleh petani. Memiliki kejelasan batas kepemilikan dalam arti tidak terjadi sengketa batas kepemilikan lahan, lokasi belum pernah dijadikan sawah sebelumnya, kemiringan lahan diutaraman dibawah 8\%, dalam satu hamparan minimal seluas 5 hektar atau sesuai skala ekonomi untuk pembukaan lahan baru, jika calon lahan terletak dilahan gambut maka ketebalan maksimal gambut adalah 1 meter dengan kedalaman pirit minimal $60 \mathrm{~cm}$. Tanah sesuai untuk padi sawah dan tidak diarahkan untuk sawah tadah hujan. Dalam RTRW, calon lokasi masuk dalam kawasan budi daya pertanian atau pengembangan budidaya pertanian. Calon lokasi tidak boleh berada dalam kawasan hutan (HPK, HP,HPT, HL, HVCA), kawasan moratorium pengembangan gambut, kawasan HGU atau kawasan yang telah dibebani hak dan izin lainnya. Lahan tidak tergenan air selama 3 bulan berturut-turut, petani ada dan berdomisili di desa calon lokasi atau berdekatan dengan calon lokasi serta berkomitmen untuk bersawah. Jika terdapat lahan yang pemiliknya tidak berdomisili di desa calon lokasi maka pemilik lahan bersedia mengikuti program perluasan sawah yang dibuktikan dengan pernyataan tertulis dan menunjuk penggarap untuk mengerjakan sawah yang akan dicetak.

Sebagai program yang salah satu tujuan utamanya adalah melindungi dan mensejahterakan petani, program pencetakan sawah baru ini diharapkan tidak saja meningkatkan kesejahteraan petani secara ekonomi, tetapi juga diharapkan dapat mendorong meningkatknya modal sosial dalam masyarakat. Peningkatan modal sosial masyarakat ini penting karena modal sosial merupakan komponen penting dalam pembangunan dan pemberdayaan masyarakat. Putnam (1993) menjelaskan bahwa modal sosial memberikan kerangka dalam mengeksplorasi bagaimana pembangunan dalam maknanya yang luas dipengaruhi oleh kepercayaan (trust), saling keterhubungan (relationship) dan jaringan sosial (network).

Berdasarkan uraian tersebut tulisan ini akan mengemukakan korelasi antara program pencetakan sawah baru dengan meningkatnya modal sosial dalam masyarakat di kecamatan 
Banjit dan kecamatan Baradatu Kabupaten Way Kanan terutama dengan melihat tiga komponen penting dalam modal sosial seperti trust, relationship, dan network yang berkembang seiring berjalannya program pencetakan sawah baru tersebut. Selain itu, tulisan ini juga menjelaskan bagaimana program pencetakan sawah baru menguatkan solidaritas sosial masyarakat yang secara khusus dianalisis menggunakan pendekatan Szreter (2002) untuk melihat aktor mana yang berperan dominan dalam pembentukan modal sosial di masyarakat.

\section{METODE PENELITIAN}

Metode yang digunakan dalam penelitian ini adalah kualitatif, sedangkan teknik yang digunakan dalam pengumpulan data melalui observasi, wawancara, dan juga pengumpulan dokumen. Dalam penelitian ini, observasi dan wawancara memiliki porsi yang besar jika dibandingkan dengan pengumpulan dokumen. Wawancara dilakukan pada beberapa masyarakat yang menjadi anggota kelompok tani yang mengusulkan lahannya untuk dicetak menjadi lahan sawah baru, dan juga aparat TNI yang menjadi bagian dalam program mencetak sawah baru. Informan kunci dalam penelitian ini adalah ketua-ketua kelompok tani yang mengusulkan tanahnya untuk menjadi lahan sawah baru. Penelitian ini dilakukan di kecamatan Baradatu dan kecamatan Banjit kabupaten Way Kanan. Beberapa karakteristik khas yang ada di dua kecamatan ini diantaranya adalah bahwa awalnya terdapat banyak masyarakat yang mengusulkan pencetakan sawah baru, namun karena adanya perubahan skema pembiayaan dan proses pencetakan sawah baru banyak pula masyarakat yang akhirnya mundur dari kesertaan program pencetakan sawah baru ini. Hal ini terjadi karena awalnya masyarakat beranggapan dapat memanipulasi program ini sehingga bisa mendapatkan uang insentif tanpa harus mencetak sawah. Namun keterlibatan TNI dalam proses pencetakan sawah baru ini membuat banyak masyarakat yang mengundurkan diri dari program. Karakteristik suku juga mempengaruhi keinginan untuk menjadi calon lokasi sawah baru. Suku jawa sangat antusias menyambut program ini sedangkan suku Lampung, Ogan, dan Semendo kurang begitu tertarik hal ini karena perbedaan kebiasaan dalam bertani dimana masyarakat tersebut secara kultur bukanlah masyarakat petani sawah.

\section{KERANGKA TEORI/KONSEP}

Pemberdayaan masyarakat adalah upaya terencana yang muaranya adalah meningkatnya kesejahteraan masyarakat. Pemberdayaan masyarakat adalah suatu konsep yang tidak bisa dilepaskan dari pergerakan sosial, seperti yang didefinisikan Lotz (1967:7), yang menyebutkan pemberdayaan masyarakat sebagai: "A movement designed to promote better living for the whole community with the active participation and on the initiative of the whole community. Selain itu, 
pemberdayaan juga tidak terlepas dari proses, kemajuan sosial dan ekonomi, partisipasi aktif, dan juga prakarsa komunitas. Hal tersebut termaktub dalam definisi yang dikemukakan oleh PBB pada tahun 1955, yang terdapat dalam Social Progress Through Community Development sebagai berikut: "Community development can be tentatively defined as a process designed to create conditions of economic and social progress for the whole community with its active participation and the fullest reliance upon the community's initiative".

Pemberdayaan masyarakat dalam praktiknya juga terus mengalami perkembangan sesuai dengan kondisi dan setting sosial masyarakat dimana pemberdayaan tersebut dilakukan. Namun sejauh ini, dapat dilihat bahwa pemberdayaan umumnya dilakukan dengan skema pembentukan kelompok. Hal tersebut diyakini telah mendorong menguatnya modal sosial masyarakat yang ditunjukkan dengan menguatnya kepercayaan, keterhubungan, dan jaringan sosial. Selain itu program pemberdayaan ini juga meningkatkan solidaritas dan kerjasama, serta keterhubungan antar kelompok petani.

Program pencetakan sawah baru yang saat ini dikembangkan di wilayah Kabupaten Way Kanan juga merupakan salah satu bentuk pemberdayaan yang dilakukan oleh pemerintah untuk mendorong peningkatan kesejahteraan masyarakat melalui kemampuan menjadi penyedia pangan bagi masyarakat. Selain program pemberdayaan dalam bentuk pencetakan sawah baru, program ini juga diikuti dengan program program pemberdayaan lainnya untuk semakin menguatkan fundamen masyarakat. Berdasarkan uraian tersebut, maka pemberdayaan melalui program pencetakan sawah baru ini akan dilihat dari sejauh mana program tersebut menguatkan modal sosial pada masyarakat petani penerima program pencetakan sawah baru yang ada di Kabupaten Way Kanan.

Penguatan kapital sosial tersebut sangat penting untuk dilihat karena teori kapital sosial memberikan kerangka didalam mengeksplorasi bagaimana pembangunan dalam maknanya yang luas dipengaruhi oleh kepercayaan (trust), saling keterhubungan (relationship) dan jaringan sosial (network). Selain itu, modal sosial juga dapat memfasilitasi akumulasi kapital fisik (physical capital), sehingga sangat penting kiranya untuk melihat bagaimana modal sosial meningkatkan investasi didalam human kapital, meningkatkan produktivitas, mengurangi kemiskinan dan meningkatkan kesejahteraan (Killerby dan Wallis, tt:26). 


\section{PEMBAHASAN}

Pencetakan Sawah Baru Sebagai Upaya Pemberdayaan Masyarakat Petani

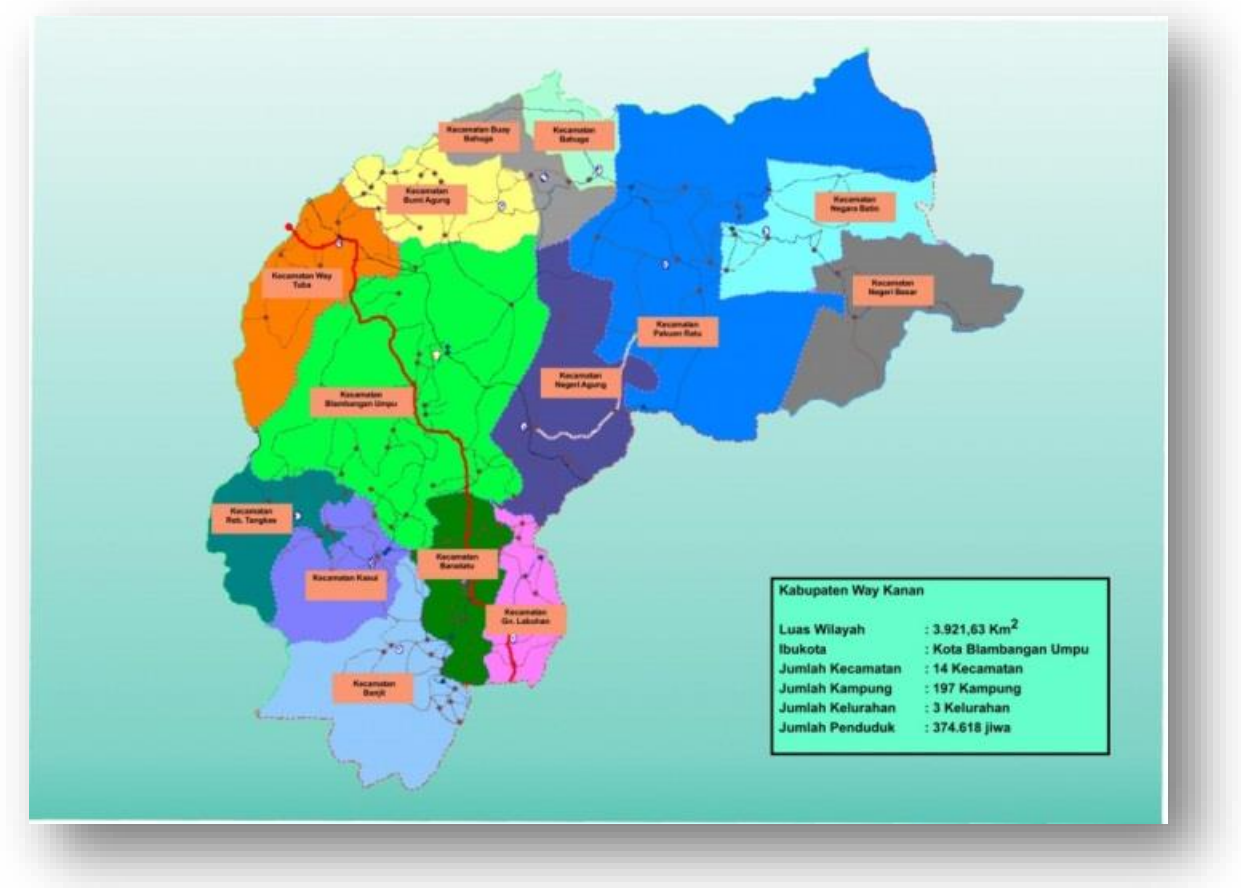

Gambar 1. Peta Wilayah Kabupaten Way Kanan

Terdapat 491 orang pengusul di kecamatan Baradatu dan Kecamatan Banjit. Dengan jumlah pengusul di masing-masing desa adalah sebagai berikut:

Tabel 1. Jumlah Pengusul Pencetakan Sawah Baru di Kabupaten Way Kanan

\begin{tabular}{llc}
\hline \hline \multirow{1}{*}{ Kecamatan } & \multicolumn{1}{c}{ Nama Desa } & $\begin{array}{c}\text { Jumlah } \\
\text { Pengusul }\end{array}$ \\
\hline \multirow{5}{*}{ Baradatu } & Banjar Sari & 3 \\
\cline { 2 - 3 } & Banjar Setia & 4 \\
\cline { 2 - 3 } & Bhakti Negara & 132 \\
\cline { 2 - 3 } & Bumi Merapi & 46 \\
\cline { 2 - 3 } & Bumi Rejo & 132 \\
\cline { 2 - 3 } & Setia Negara & 37 \\
\cline { 2 - 3 } & Suko Sari & 27 \\
\cline { 2 - 3 } Banjit & Tiuh Balak Pasar & 22 \\
\hline \multirow{5}{*}{ Menangga Jaya } & 49 \\
\cline { 2 - 3 } & Menagga Siamang & 23 \\
\cline { 2 - 3 } & Neki & 42 \\
\cline { 2 - 3 } & Simpang Asam & 491 \\
\cline { 2 - 3 } & Sumber Sari & \\
\hline
\end{tabular}

Sumber: Survey dan Investigasi, 2016 
Calon petani di kecamatan Baradatu umumnya berpendidikan SMP dan SMA. Sedangkan di Kecamatan Banjit di dominasi oleh calon petani dengan pendidikan SD. Meskipun dikecamatan tersebut terdapat calon petani dengan pendidikan SMP dan SMA namun jumlahnya jauh lebih sedikit dibanding calon petani dengan pendidikan SD. Selanjutnya jika dilihat dari pekerjaannya, seluruh pengusul pencetakan sawah baru tersebut merupakan petani sehingga untuk mengembangkan produktivitas pertanian hanya dibutuhkan penyuluhanpenyuluhan yang bersifat teknis.

Adapun luasan lahan yang diusulkan untuk dicetak sawah baru di kecamatan Banjit dan Baradatu adalah seluas 453,7 hektar. Dengan jumlah pengusul sebesar 490 orang maka dapat dilihat bahwa luas lahan yang diusulkan untuk dicetak menjadi sawah sangatlah beragam. Keberagaman luasan lahan yang diusulkan ini memungkinkan terjadinya perbedaan pendapatan antar masing-masing petani. Disisi lain, kecilnya lahan yang diusulkan untuk dicetak menjadi sawah baru ini juga merupakan strategi yang dilakukan masyarakat untuk menekan biaya produksi pertanian, sehingga tidak diperlukan tenaga upahan untuk mengelola dan menggarap sawah tersebut.

Secara ekonomi hasil survey memperlihatkan bahwa rata-rata pengeluaran harian calon petani adalah sebesar 50.000 rupiah, dengan melihat jumlah anggota keluarga yang dimiliki oleh masing-masing petani maka angka tersebut tergolong kecil, sehingga dapat pula dikatakan bahwa masyarakat calon petani di kecamatan Banjit dan Baradatu ini merupakan masyarakat yang tergolong miskin.

Apa yang telah diuraikan tersebut secara jelas memperlihatkan bahwa permasalahan utama yang dihadapi masyarakat calon petani di Kecamatan Banjit dan Kecamatan Baradatu kemiskinan, dengan mengusulkan lahannya untuk dicetak menjadi sawah ini merupakan strategi untuk meningkatkan kesejahteraan keluarga.

Program pencetakan sawah baru ini jika dilihat dalam konteks pemberdayaan masyarakat merupakan upaya memecahkan permasalahan sosial dan ekonomi dalam masyarakat petani di dua kecamatan tersebut dengan membangun suatu sistem sehingga masyarakat mampu menolong dirinya sendiri. Dengan kata lain dapat dikatakan bahwa program pencetakan sawah baru yang digulirkan oleh pemerintah ini merupakan upaya mendorong masyarakat untuk memberdayakan diri mereka sendiri dengan mengoptimalkan sumberdaya yang dimiliki oleh mereka sendiri yang didukung oleh upaya pembinaan dan pendampingan yang dilakukan oleh pemerintah. 
Seperti dikemukakan sebelumnya bahwa beragamnya luasan lahan yang diusulkan oleh petani tersebut mengindikasikan bahwa pencetakan sawah baru ini merupakan upaya yang dikembangkan oleh masyarakat petani pengusul untuk mempertahankan kelangsungan kehidupan keluarga. Petani pengusul tidak serta-merta merubah seluruh lahan yang dimilikinya menjadi sawah, tetapi tetap mempertahankan sebagian lahannya dengan tanaman perkebunan, palawija, ataupun sayuran. Dengan ikutnya pengusul pada program pencetakan sawah baru ini maka masyarakat petani tidak perlu lagi membeli beras untuk kebutuhannya sehari-hari, karena sudah dapat dipenuhi oleh sawah baru yang dimiliki tersebut. Dengan begitu maka pengeluaran untuk memenuhi kebutuhan beras keluarga tidak perlu lagi dikeluarkan, dan kelebihan panen dari masing-masing tipe pertanian yang dipertahankan tersebut juga dapat dikonversi menjadi uang, sehingga untuk memenuhi kebutuhan-kebutuhan lainnya masyarakat juga memiliki uang.

Dapat dilihat bahwa selain sebagai upaya menjaga ketahanan pangan, program ini juga merupakan upaya pemberdayaan yang dilakukan oleh pemerintah pada masyarakat petani. Skema pengusulan cetak sawah baru yang dilakukan secara berkelompok memperlihatkan bahwa pemerintah lokal khususnya dinas pertanian juga mendorong menguatnya modal sosial dalam masyarakat petani tersebut. Hal tersebut terjadi karena berkembangnya kelompokkelompok tani yang aktif akan mendorong perbaikan pelayanan pada pemerintah lokal.

\section{Pembentukan Kelompok dan peningkatan Modal Sosial Petani}

Dijadikannya masyarakat pengusul pencetakan sawah baru kedalam kelompok-kelompok tani akan memudahkan pemerintah melakukan pembinaan, penguatan dan juga pengawasan program, sehingga target-target capaian yang diinginkan pemerintah dapat tercapai.

Pada level masyarakat, pembentukan kelompok tani ini juga mendorong adanya peningkatan kapasitas dan pengetahuan karena adanya penyuluhan yang dilakukan secara berkala dimana dalam penyuluhan tersebut juga disampaikan berbagai macam pengetahuan pertanian dan memecahkan permasalahan pertanian sawah yang dikembangkan tersebut.

Adanya petani pengusul yang secara terbuka menggabungkan diri dalam kelompok tani tersebut menunjukkan terbentuknya semangat saling percaya. Dimana dalam kelompok tersebut terdapat keragaman latar belakang pendidikan, usia, pengalaman tentunya akan menjadi penguat. Disisi lain, keberadaan kelompok tersebut juga mendorong munculnya kepercayaan dari pemerintah. Meningkatnya kepercayaan pemerintah tersebut dibuktikan dengan dilakukannya perubahan skema pemberian dana pencetakan sawah. Dari berupa pemberian uang sebagai biaya pencetakan sawah, menjadi pemberian lahan sawah yang sudah 
dicetak dimana dalam pencetakan sawah tersebut pemerintah melibatkan peran TNI. Perubahan skema ini karena terjadinya selisih usulan lahan yang ingin dicetak dengan realisasi.

Terjadinya perubahan skema ini juga menjadi seleksi alami bagi calon penerima program, dengan demikian maka upaya-upaya manipulatif baik yang dilakukan oleh pemerintah maupun yang dilakukan oleh masyarakat pengusul dapat ditekan.

Selanjutnya, penguatan trust juga terlihat dari keyanikan calon petani pada kemampuan pemerintah lokal untuk membangun infrastruktur penunjang pertanian sawah, seperti perbaikan aliran irigasi. Hasil survey menunjukkan bahwa dua kecamatan ini dulunya merupakan areal pertanian padi. Namun karena kendala irigasi yang tidak mampu mengairi seluruh lahan sawah yang ada maka banyak lahan sawah yang beralih fungsi. Sejauh ini, meskipun perbaikan irigasi tersebut belum terjadi namun dengan adanya kelompok-kelompok tani baru yang mengusahakan lahan sawahnya telah mendorong pemerintah lokal lebih responsif dalam mendukung tercapainya target ketahan pangan melalui program pencetakan sawah baru ini. Hal tersebut seperti dikatakan Edi Irawan salah satu pengusul di Kecamatan Banjit, sebagai berikut:

\begin{abstract}
"Kami sebetulnya memiliki keraguan yang disebabkan ketersediaan air sehingga membuat petani ragu - ragu. Sebagian besar calon lokasi yang kami usulkan telah memiliki irigasi teknis yang dibangun sekitar tabun 1980an namun sekitar tabun 1990an aliran air menuju kecamatan baradatu sudah tidak pasti karena aliran air dari bendungan way umpu lebih diprioritaskan pada lokasi sawah yang berada dikecamatan banjit. hal ini menyebabkan petani lebih memilib untuk menanam kayu - kayuan dan palawija yang tidak membutubkan air banyak. selain itu 90\% jaringan irigasi teknis telah rusak dan memerlukan perbaikan. Meskipun masih dapat digunakan namun distribusi air menjadi tidak efisien karena banyak bilang dalam perjalanan. Saat ini sedang dibangun bendungan way besai yang aliran airnya nantinya dikbususkan untuk menagairi areal pertanian di kecamatan baradatu." (Wawancara tanggal 20 September 2016)
\end{abstract}

Program pencetakan sawah baru ini juga memungkinkan adanya keterhubungan antara satu kelompok tani dengan kelompok tani yang lainnya. Keterhubungan tersebut terlihat dari berkembangnya proses musyawarah yang berkembang antara kelompok untuk sama-sama menemukan solusi mendapatkan aliran air untuk mengairi sawahnya.

Adapun pada penguatan jaringan, dibentuknya kelompok-kelompok tani tersebut telah meningkatkan posisi tawar masyarakat pada pemerintah, dimana dalam perencanaan proyekproyek infrastruktur irigasi yang dibangun, kelompok-kelompok tani tersebut dapat memberikan usulan dan masukan sehingga kepentingan masing-masing kelompok tani agar produktivitas pertaniannya baik dapat menjadi masukan bagi pemerintah.

Pembentukan kelompok tani penerima program yang dikembangkan oleh pemerintah ini juga secara langsung memudahkan pemerintah dalam menyalurkan program-program 
pemberdayaan lainnya. Sehingga program pencetakan sawah baru ini juga diikuti dengan program-program pendukung lainnya sehingga pemberdayaan masyarakat petani tersebut dapat berjalan secara maksimal. Beberapa program lainnya yang mengikuti program pencetakan sawah ini diantaranya adalah bantuan bibit dan pupuk bersubsidi, penyuluhan dan penguatan kelompok usaha tani, serta bantuan insentif lainnya yang menunjang hasil program yang maksimal.

\section{SIMPULAN}

Pendekatan program pencetakan sawah baru dengan membentuk kelompok tani seperti dilakukan di kabupaten Way Kanan ini memperlihatkan munculnya saling percaya antara pemerintah dan masyarakat hal tersebut ditunjukkan dengan adanya komitmen pemerintah memperbaiki aliran irigasi dan komitmen masyarakat untuk menggarap sawahnya. Pembentukan kelompok ini juga telah mendorong komunikasi yang efektif antara pemerintah dan masyarakat petani, sehingga setiap rencana pembangunan bidang pertanian selalu disesuaikan dengan kebutuhan masyarakat.

Pembentukan kelompok tersebut juga memungkinkan masyarakat memiliki posisi tawar yang baik dengan tingkat kerjasama juga yang sudah semakin baik. Dari situ maka dapat dilihat bahwa program pencetakan sawah baru yang mengedepankan pendekatan kelompok seperti yang dikembangkan oleh pemerintah ini telah mendorong meningkatnya modal sosial masyarakat, yang dibuktikan dengan adanya peningkatan kepercayaan, kerjasama, dan penguatan jaringan ditingkat petani.

\section{DAFTAR PUSTAKA}

Anantanyu, S. 2011. Kelembagaan Petani: Peran dan Strategi Pengembangan Kapasitasnya. Jurnal SEPA: Vol. 7 No. 2 Februari 2011: 102-109

Candland, Christopher.2000.Faith as social capital: Religion and community development in Southern Asia in Policy Sciences Vol 33, No. 3,4, December 2000 pp. 129-148

Coleman, J.S.1988.'Social Capital in the Creation of Human Capital The American Journal of Sociology 94:S95-S120.

Direktorat Jenderal Prasarana dan Sarana Pertanian. 2017. Pedoman Teknis Survey, Investigasi dan Desain (SID) Perluasan Sawah Tahun 2017. Kementerian Pertanian Republik Indonesia

Direktorat Perluasan dan Pengelolaan Lahan. 2013. Cetak Sawah Indonesia. Direktorat Jenderal Prasarana dan Sarana Pertanian Kementerian Pertanian Republik Indonesia

https:// finance.detik.com/berita-ekonomi-bisnis/3533461/kementan-cetak-sawah-programnawacita-jokowi

https://katadata.co.id/berita/2017/11/06/bpk-pertanyakan-status-lahan-pada-programcetak-sawah-kementan-tni 
Desi Yunita, Ahmad Thariq

Killerby, Paul and Wallis, J.2002. Social Capital and Social Economics. In Forum for Social Economics (Vol. 32,No. 1, pp.21-32). Taylor \& Francis Group

Lotz, Jim.1967.Introduction: Is Community Development Necessary? in Anthropologica, New Series, Vol. 9, No. 2, Community Development in Canada (Socio-Economic Development) (1967), pp. 3-14

Putnam, Robert D.1993.Making Democracy Work Civic Traditions in Modern Italy.New Jersey:Princeton University Press

Putnam, Robert D.1993.Making Democracy Work Civic Traditions in Modern Italy.New Jersey:Princeton University Press

Szreter, Simon.2002.'The State of Social Capital:Bringing Back in Power, Politics, and History' Theory and Society 31,5:573-621

83 | SGSIOGLLBAL : Jurnal Pemikiran dan Penelitian Sasiologi, Vol. Z, №. I, Desember 2017 